\title{
Practice and Exploration on the Teaching Mode of "Combination of Work and Study" in Five-year Higher Vocational Education
}

\author{
Zhiling Wang \\ Jiangsu province xuzhou technician institute \\ Xuzhou, Jiangsu 221151, China \\ 379713268@qq.com
}

\begin{abstract}
Through the full investigation of the training mode of welding automation professionals and the employment and job adaptability of graduates in our institute, it is pointed out that the current mode of personnel training is too formalized, the proportion of course content of teaching content theory is serious, and the theoretical knowledge is out of line with practice teaching. The practice of teaching is out of line with enterprise production, graduates need to go through the second training of enterprises and then go to work, comprehensive professional quality is not high and so on. The purpose of this paper is to explore the new mode of cooperation between schools and enterprises, which is suitable for the development of higher vocational education, the high degree of enterprise identity and the quality of education and teaching.
\end{abstract}

Keywords-Five-year higher vocational education; Combination of work and study; Study Teaching mode

\section{INTRODUCTION}

With the development of new industrialization process, the welding technology is undergoing structural transformation. The modern welding technology, which is characterized by high efficiency, energy saving, high quality and its process digitization, automation and intelligent control, gradually replace the traditional welding process with high energy consumption and low efficiency. However, the research that China's current production line of high-quality talent is not only a serious lack of quality, and vocational colleges transport graduates, most of the lack of productive processing base, a serious impediment to the development process. Through the investigation of teaching mode of the teaching mode of the welding automation specialty and the employment and job adaptability of the graduates, it is considered that the current mode of personnel training is too formalized, the proportion of the course of teaching content theory is too heavy, the form of education is too single, the theoretical knowledge and practice teaching are out of touch Teaching and enterprise production out of line, leading to comprehensive professional quality of students is not high, graduates need to go through the second training of enterprise to work and so on. So as an example to improve student professional knowledge and operational knowledge and operational skills, the accumulation of more work experience, reduce training costs. Cultivate students' job awareness and team awareness and other professional quality. Enhance cooperation between schools and enterprises. Please participate in the enterprise industry experts, to participate in the personnel training process, to promote the quality of school; to provide staff training, to solve research and development problems and other services to promote the healthy development of cooperative relations; promote production processes, reduce labor costs, better value- added profits, Local economy. Our institution to Xugong Group, Cater and other well-known enterprises as a student practice base, and actively promote the combination of work and study, the reform of our institution 5-year vocational training mode, the practice of teaching content and business needs convergence, Post requirements "Zero" distance of talent to become an important and urgent subject, it is worth in-depth study.

Many researchers have introduces the advanced experience of combining foreign employment with the combination of industry and academia, but the successful practice of foreign countries must be combined with china's national conditions, regional differences and the actual level of vocational and technical education development can not copy . Therefore, deeping and improving the characteristics of the region and the school-school cooperation in the combination of teaching and learning personnel training model, still need further exploration, but also need to boldly innovate. One of the most critical issue is how to achieve the school and the employer between the height and close cooperation, how to build schools and enterprises can fully accept the co-operation mode, how to strengthen the internship during the counseling.

This article draws lessons from the German "dual system" personnel training mode, for our country vocational colleges to provide personnel training mode management new ideas, helps to promote the scientist development of our country higher education mode, helps to improve the quality of teaching, Students in the process of learning can really do the theory with practice. And then promote the training of higher vocational colleges for personnel training model, making the diversification of vocational education training model. From the perspective of cross -cultural management to explore the training mode of higher vocational talents, and further 
promote the market economy under the vocational training of personnel training model.

\section{THE RESEARCH VALUE OF THE “COMBINATION OF WORK AND STUDY" TEACHING MODEL}

Teaching and learning is a well-known educator Mr. Tao Xingzhi's methodology, which is the vocational school "school-enterprise cooperation, work and study" embodied in the educational goals are consistent. This paper characterized as "work and study" changes the traditional Teaching and training programs to build a new combination of school and enterprise teaching model, so as to comprehensively inprove the quality of teaching and enhance the professional social service capabilities, lead and improve the professional development of welding professional groups.

\section{A. The first value of carrying out the exploring of the combination of teaching and learning model is helping students master the skills to improve the overall quality}

The real production production environment can reflect the consistency of internship and practical work, it is beneficial to improve the students' professional skills and comprehensive quality. At the same time, productive training is often part of subsidy, students' self-awareness, and sense of accomplishment to stimulate; secondly, is conducive to the full use of school equipment, education and teaching and social services to improve. The long-term use of the infrastructure of the welding training center reduces the cost of equipment investment and student intership costs. The school can use more energy and financial resources to invest in new curriculum construction and teaching reform, and realize the social service function to a higher degree. Thirdly, the profitability of the enterprise. Enterprises not only reduce the infrastructure did not put the investment, greatly reducing the investment cycle, but also get a lower cost of labor.

\section{B. Carrying out the depth of school-enterprise cooperation to promote the socio-economic development}

At present, the country's economic development mode gradually changed from extensive to intensive, the key to this change is the need for high-quality highly skilled personnel, vocational schools are mainly to cultivate production, construction, service first-line technology applied talents, this goal of the vocational education should be in accordance with the requirements of social and economic development to train the first line of professional positions and technical fields of technology applied talents. China's traditional education is the school's classroom-centered talent training model, this model of student knowledge theory, can not be effectively used for practice, there is a theory and practice of the phenomenon of disjunction, can not learn to use, so that Production teaching out of touch, can not meet the requirements of vocational education.

\section{Integration of "new apprenticeship", innovation "teaching and learning "model, training highly skilled personnel}

In the deepening of cooperation between schools and enterprises, the school gradually realized that the teaching practice sites, productive training places cooperation, but the initial, practical cooperation, to make school-enterprise cooperation towards a higher level, go Farther, more dynamic, more competitive, it is necessary in the technical R and D and process improvement and other aspects of deep - level integration.

The consumption of internships into productive internships the implementation of part-time work-study mode of alternating learning, not only save the cost of practice, but also to enable students to understand the real production practice business, skilled master production technology and operational skills, not out of school to become skilled master. The cultivation of skilled personnel, must be through the schoolenterprise cooperation in the practice of practice, so that students practice training places from school to business, from the simulation of the training sites extended to the real knife and gun production sites, the practice ability of students is particularly important.

\section{To carry out the depth of school-enterprise cooperation to} achieve the purpose of school-enterprise win-win situation

In the past, a long time school-enterprise cooperation, in the real operation and implementation process may encounter many problems, students practice time is short, just familiar with the job may be back to school practice, or just to visit the enterpreise, this cooperation on although the professional skills of students have a certain increase in the resourse have a certain share, but for enterprise, the meaning is not great. And carry out the depth of school-enterprise cooperation, we must take the school- enterprise win-win in the first place. So to find a company can save employees, reduce capital expenditure, but also can use the enteprise resourse for students to provide learnig resources.

\section{THE RESEARCH OBJECTIVES AND CONTENT OF "WORK AND STUDY “TEACHING MODEL}

\section{A. The research objectives of this paper}

Through extensive social research and extensive negotiations, our institution and cooperative enterprises to carry out the depth of school-enterprise cooperation, innovation in our institution 5 years of vocational education teaching model, establish a good school-enterprise cooperation mechanism, broaden the employment channels. Adjust the professional curriculum, curriculum standard, the implementation of teaching plans to school and corporate common interests as the core, to create "engineering and engineering teaching model, improve students' professional skills.

\section{B. The research content of this paper}

This paper aims to study the traditional course system of welding automation, analyze the problems in the course of education and teaching, and combine with the research situation of enterprises in production, around the "engineering alternately"talent . Training mode requirements, we have to ajust some of the curriculum, the relevant curriculum standard, modify the old implementation of teaching plans, innovation 
and school-enterprise cooperation model, developed for our institution welding automation professional "combination of work and study" talent model teaching methods under the personnel training program.

\section{The research process of "work and study "teaching model}

a) Develop the enterprises that suitable for the establishment of the deep school-enterprise cooperation.

To ensure that schools and enterprises to establish longterm depth of cooperation, the need for schools and enterprises from the actual stituation, a comprehensive analysis of whether the two sides to establish such a depth of the relationship.

\section{b) Establishing the Student Practice Study Steering} Committee.

To ensure the depth of the school-enterprise cooperation model of the smooth inplementation of the need for schools and enterprises to participate in the establishment of student practice study Steering Committee.

c) Doing the enterprise research, Analyzing the research data, Writing research reports.

d) Adjust the curriculum system, compose the relevant teaching materials, rearrange the implementation of teaching palns.According to the production needs of enterprises, adjust the relevant courses, the learning settings of the subject. At present, part of the teaching materials of vocational schools are isolated, without realizing the integration of knowledge , leading to students do not have a clear goal in the process of knowledge trasfering, and can not master the knowledge systematically. Therefore, according to the needs of the job, on the basis of the necessary and sufficient, knowledge should be merged, the school-based teaching materials suitable for the depth of school-enterprise cooperation should be compiled the theoretical knowledge should be modularize, and the curriculum. To make the teaching plans that suitable for school and enterpreises to cultivate students together.

e) To make the new education and teaching system.

According to the new curriculum arrangement, standards,implementation of teaching plans, make the new school-enterprise cooperation training model

f) To establish the evaluation system of students' practice learning.

Vocational education is in order to cultivate the highquality workers and senior technical personnel those can adapt to the production, construction, management, service needs of the first line. With the school-enterprise cooperation improving in the breadth ,depth and height ,the traditional assessment methods can not fully and scientifically reflect the quality of students. Students assessment and evaluation of results must be from the enterprise and the school in many aspects, multiple levels of assessment. The perfect evaluation system includes the principles, contents,methods and assessment criteria of the assessment, so as to ensure that the students can not only acquire the professional skilld in the whole practice learning process, but also improve the comprehensive abbility.

Through the study of the combination of work and study system, we have drawn that from the curriculum arrangement, curriculum standards, teaching materials, module teaching mode to the influence of corporate culture, we should focus on the " combination of work and study"teaching model of teaching, practice, production, relearning and reproduction. All the practice teaching modules should be reflected the "work and study alternating" talented people cultivating model of completing the teaching task in the production and completing the production task in practice teaching. All of the above process should be interlocking, can not exist in isolation Both to solve the production costs, but also to ease the shortage of busness land and skilled workers and other issues. At the same time to solve the problem of cultivating model of half- work andhalf- study .Not only save the cost of practice , but also to enable students to understand the real production practice, proficient in production technology and operatioal skillsand then become a skilled masterbefore graduate from school.

\section{CONCLUSION}

This paper analyzes the problems in the teaching and teaching process by studying the traditional system of welding automation and the research of "alternate engineering" talents in production. Proposed to adjust the relevant curriculum standards, modify the old implementation of the teaching plan, innovation and school-enterprise cooperation model for our organization welding automation professional "work and learning combined" talent model development personnel training program under the teaching methods, developed a new education and teaching system , Greatly improving the employment of graduates to adapt to the cost of production.

\section{REFERENCES}

[1] Li Shuming. Reflection on the practice of combining work with learning in Higher Vocational Colleges [J]. Chinese higher education research. 2009 (08)

[2] Xie Wenjing. Exploring the teaching standard of Vocational and technical education in combination of work and study. [J]. higher education exploration. 2009 (04)

[3] Liao Jianhua, Liu Huijuan. Construction of talent training model of combining work with learning in Higher Vocational Colleges [J]. Vocational and technical education. 2009 (16)

[4] Zhai Yanhui. Exploration and Reflection on the mode of combining work with learning and school enterprise cooperation in Higher Vocational Colleges [J]. China Adult Education. 2009 (14)

[5] Liu Hua. Exploration of the operational mechanism of talent training mode of combining work with learning in Higher Vocational Colleges [J]. Education exploration. 2009 (08)

[6] Pan Chunsheng. Analysis and Countermeasures of difficulties in combining work with learning in Higher Vocational Education [J]. China Vocational and technical education. 2009 (21) 